\title{
POSTURAL EFFECTS ON RENAL TUBULAR ACTIVITY ${ }^{1}$
}

\author{
By A. SURTSHIN AND H. L. WHITE
}

\author{
(From the Department of Physiology, Washington University School of Medicine, \\ St. Louis, Mo.)
}

(Submitted for publication October 10, 1955; accepted October 27, 1955)

A number of observers have reported that acute reduction of glomerular filtration rate (GFR) in experimental animals induces a considerable fall in renal excretion of sodium and water. Chronic constriction of one renal artery is followed by persistent fall in salt and water excretion by that kidney (1). In man, change from the recumbent to the erect position is followed by a considerable fall in urinary flow and sodium excretion and by small decrease in inulin and exogenous or endogenous creatinine clearances $(2-4)$. The above findings were on subjects not in maximal water diuresis. In human subjects with a large water load who had been sitting for four to eight hours, change to recumbency was followed by increase in urine flow, sodium excretion and sodium urinary concentration while creatinine $\mathrm{U} / \mathrm{P}$ ratios fell and endogenous creatinine clearance rose slightly (5).

Whether more nearly complete reabsorption of sodium and water following maneuvers reducing GFR is accomplished in the proximal or the distal segment of the tubule is not certain. Pitts and Duggan $(6,7)$ inferred that organic mercurial diuretics depress the distal reabsorption of sodium, and after observing that aortic constriction produced marked fall in sodium excretion even after administration of a large dose of Mercuhydrin ${ }^{\mathbb{8}}$ in dogs they concluded that the increased sodium and water reabsorption resulting from fall in GFR takes place in the proximal segment. The inference that mercurial diuretics act solely distally has been supported $(8)$ and rejected $(9,10)$ and the loci of the more complete reabsorption remain unidentified.

As has been reviewed previously (4) most workers have found a fall in GFR with postural change from the horizontal to a head-up tilt or standing. We here report the effects of postural change on the excretion of water, sodium, creatinine and os-

1 Aided by grant A-92 (C4), National Institutes of Health. USPHS. motically active solutes in normal human subjects in maximum zeater diuresis. We have attempted to localize within the nephron some of the changes observed, using the following assumptions: 1) Distal water reabsorption is abolished in maximum water diuresis with the subject at ease, recumbent or standing (11). 2) Proximal reabsorption is isotonic (12-15). Evidence for the first assumption is that urine flow in maximal water diuresis or in complete diabetes insipidus about equals the volume of fluid leaving the proximal tubules, as estimated by observations on proximal fluid samples obtained by micropuncture (13).

If it should be found that the percentage fall in water excretion on changing from recumbency to standing with subjects in maximal water diuresis is significantly greater than the percentage fall in GFR it would follow that the percentage of filtered water reabsorbed proximally is increased on standing. Since proximal reabsorption is considered as isotonic, the percentage of filtered sodium reabsorbed proximally is also increased. If it should further be found that urine and plasma osmolarity remain unchanged, free water clearance also shows a greater percentage fall than does GFR. This means that distal reabsorption of osmotically active solutes, largely sodium salts, without water shows a greater percentage fall than does GFR, and since distal reabsorption of water is taken as zero, distal reabsorption of solute leading to free water is the same as total distal reabsorption of solute. We would thus conclude that on changing from recumbency to standing in maximum water diuresis the percentage of filtered water and sodium reabsorbed proximally is increased, while the percentage (and absolute amount per unit time) of sodium reabsorbed distally is decreased. The same conclusions would follow from any combination of circumstances leading, in maximal water diuresis, to a greater percentage fall in urine flow and free water clearance than in GFR. Although we have used sub- 
jects in maximal water diuresis in order to equate volume delivered to the distal segment with urine flow (assumption 1), we have no reason to believe that the postural responses of the proximal segment in the reabsorption of water or sodium, or of the distal segment in the reabsorption of sodium, would be any different at lower urine flows.

\section{METHODS}

Subjects reported to the laboratory between 8:00 and 9:30 A.M. after having had a light breakfast without added salt, and water ad libitum, but no other food since about the previous 7:00 P.M. They drank 1,200 cc. of tap water in 10 or 15 minutes, emptied their bladders and then either lay down on a cot or remained standing.
Every 20 minutes thereafter for 1 hour (3 doses) they drank 300 cc. of tap water. The bladder was emptied at the end of the first hour, urine volume was recorded and the positive water load $(2,100 \mathrm{cc}$. minus urine volume) was maintained constant thereafter, neglecting extrarenal water loss. After the first hour the bladder was emptied every 15 minutes and an amount of tap water equal to the volume of urine passed was drunk. The procedure was continued until urine flow was reasonably constant for four or more periods when a venous blood sample was taken. After one or two additional periods (during which urine flow did not diminish) change in posture from supine to standing or vice versa was effected with voiding and drinking continued as before. The new posture was maintained until five or more consecutive periods with constant urine flow were obtained. Another venous blood sample was then taken

TABLE I

Postural effects on urine flow and solute excretion *

\begin{tabular}{|c|c|c|c|c|c|c|c|c|c|c|c|c|}
\hline $\begin{array}{c}\text { Subject, } \\
\text { Date }\end{array}$ & $\begin{array}{l}\text { Posture } \\
\text { change }\end{array}$ & $\begin{array}{c}\text { Water } \\
\text { load } \\
c c .\end{array}$ & $\begin{array}{c}\text { Creat. } \\
\text { clear. } \\
\text { ce. } / \text { min. }\end{array}$ & $\begin{array}{c}\text { Urine } \\
\text { flow } \\
c c . / \text { min. }\end{array}$ & $\begin{array}{c}\text { Urine } \\
\text { Na } \\
m E q . / L .\end{array}$ & $\begin{array}{c}\text { Urine } \\
\text { Na } \\
\mu E q . / m i n .\end{array}$ & $\begin{array}{c}\text { Urine } \\
\text { solutes } \\
m 0 s . / L .\end{array}$ & $\begin{array}{c}\text { Urine } \\
\text { solutes } \\
\text { mos. } / \text { min. }\end{array}$ & $\begin{array}{c}\text { Plasma } \\
\text { solutes } \\
m 0 s . / L .\end{array}$ & $\begin{array}{c}\text { Osmol. } \\
\text { clear. } \\
\text { cc. } / \text { min. }\end{array}$ & $\begin{array}{c}\begin{array}{c}\text { Free } \\
\text { water } \\
c c . / m i n .\end{array} \\
.\end{array}$ & $\begin{array}{c}\text { Creat. } \\
\mathbf{U} / \mathbf{P}\end{array}$ \\
\hline \multirow[t]{2}{*}{$\begin{array}{l}\mathrm{H} \mathrm{W} \\
3 / 16\end{array}$} & L-S $†$ & 1,700 & 100 & 8.46 & 10.6 & 85.7 & 70.5 & .598 & 275.0 & 2.17 & 6.29 & 11.8 \\
\hline & & & $\begin{array}{r}108 \\
.92\end{array}$ & $\begin{array}{r}15.4 \\
.55\end{array}$ & $\begin{array}{r}17.2 \\
.62\end{array}$ & $\begin{array}{r}265 \\
.32\end{array}$ & $\begin{array}{r}74.5 \\
.95\end{array}$ & $\begin{array}{r}1.15 \\
.52\end{array}$ & 275.0 & $\begin{array}{r}4.19 \\
.52\end{array}$ & $\begin{array}{r}11.2 \\
.56\end{array}$ & $\begin{array}{r}7.2 \\
1.64\end{array}$ \\
\hline \multirow[t]{2}{*}{$3 / 25$} & S-L & 1,860 & 75.9 & 7.15 & 3.22 & 23.1 & 64.5 & .477 & & 1.73 & 5.42 & 10.7 \\
\hline & & & $\begin{array}{r}89.9 \\
.84\end{array}$ & $\begin{array}{r}11.2 \\
.64\end{array}$ & $\begin{array}{r}11.6 \\
.28\end{array}$ & $\begin{array}{r}130 \\
.18\end{array}$ & $\begin{array}{r}67.0 \\
.96\end{array}$ & $\begin{array}{r}.721 \\
.66\end{array}$ & 276.0 & $\begin{array}{r}2.61 \\
.66\end{array}$ & $\begin{array}{r}8.59 \\
.63\end{array}$ & $\begin{array}{r}8.1 \\
1.32\end{array}$ \\
\hline \multirow[t]{2}{*}{$\begin{array}{l}\text { WS } \\
3 / 18\end{array}$} & L-S & 1,920 & 145 & 12.5 & 7.16 & 90.0 & 63.5 & .797 & 278.5 & 2.86 & 9.64 & 11.6 \\
\hline & & & $\begin{array}{r}145 \\
1.00\end{array}$ & $\begin{array}{r}14.4 \\
.87\end{array}$ & $\begin{array}{r}8.23 \\
.87\end{array}$ & $\begin{array}{r}119 \\
.76\end{array}$ & $\begin{array}{r}69.5 \\
.91\end{array}$ & $\begin{array}{r}1.01 \\
.79\end{array}$ & 292.0 & $\begin{array}{r}3.44 \\
.83\end{array}$ & $\begin{array}{r}11.0 \\
.88\end{array}$ & $\begin{array}{l}10.0 \\
1.16\end{array}$ \\
\hline \multirow[t]{2}{*}{$6 / 27$} & S-L & 1,878 & 117 & 16.6 & 4.81 & 79.8 & 53.5 & .886 & 282.0 & 3.14 & 13.5 & 7.2 \\
\hline & & & $\begin{array}{r}122 \\
.96\end{array}$ & $\begin{array}{r}18.7 \\
.89\end{array}$ & $\begin{array}{r}7.40 \\
.65\end{array}$ & $\begin{array}{r}138 \\
.58\end{array}$ & $\begin{array}{l}49.0 \\
1.09\end{array}$ & $\begin{array}{r}.915 \\
.97\end{array}$ & 286.5 & $\begin{array}{r}3.19 \\
.97\end{array}$ & $\begin{array}{r}15.5 \\
.87\end{array}$ & $\begin{array}{r}6.5 \\
1.11\end{array}$ \\
\hline \multirow[t]{2}{*}{$\begin{array}{l}\text { M K } \\
6 / 21\end{array}$} & L-S & 1,895 & 115 & 10.3 & 14.0 & 145 & 73.0 & .753 & 275.0 & 2.73 & 7.57 & 11.4 \\
\hline & & & $\begin{array}{r}116 \\
.99\end{array}$ & $\begin{array}{r}15.3 \\
.67\end{array}$ & $\begin{array}{r}16.2 \\
.86\end{array}$ & $\begin{array}{r}247 \\
.59\end{array}$ & $\begin{array}{r}80.0 \\
.91\end{array}$ & $\begin{array}{r}1.22 \\
.62\end{array}$ & 276.5 & $\begin{array}{r}4.41 \\
.62\end{array}$ & $\begin{array}{r}10.9 \\
.69\end{array}$ & $\begin{array}{r}7.4 \\
1.54\end{array}$ \\
\hline \multirow[t]{2}{*}{$7 / 18$} & L-S & 1,670 & 130 & 12.8 & 14.2 & 181 & 66.0 & .842 & 272.0 & 3.11 & 9.69 & 10.2 \\
\hline & & & $\begin{array}{r}133 \\
.98\end{array}$ & $\begin{array}{r}17.0 \\
.75\end{array}$ & $\begin{array}{r}19.3 \\
.74\end{array}$ & $\begin{array}{r}333 \\
.54\end{array}$ & $\begin{array}{r}75.5 \\
.87\end{array}$ & $\begin{array}{r}1.28 \\
.66\end{array}$ & 270.5 & $\begin{array}{r}4.74 \\
.66\end{array}$ & $\begin{array}{r}12.3 \\
.79\end{array}$ & $\begin{array}{r}7.8 \\
1.31\end{array}$ \\
\hline \multirow[t]{3}{*}{$\begin{array}{c}\text { AS } \\
8 / 18\end{array}$} & L-S & 1,897 & 85.0 & 12.2 & 9.86 & 120 & 60.0 & .731 & 274.0 & 2.65 & 9.55 & 7.0 \\
\hline & & & $\begin{array}{r}89.5 \\
.95\end{array}$ & $\begin{array}{r}15.6 \\
.78\end{array}$ & $\begin{array}{r}10.4 \\
.95\end{array}$ & $\begin{array}{r}162 \\
.74\end{array}$ & $\begin{array}{r}61.5 \\
.98\end{array}$ & $\begin{array}{r}.954 \\
.77\end{array}$ & 277.5 & $\begin{array}{r}3.46 \\
.77\end{array}$ & $\begin{array}{r}12.1 \\
.79\end{array}$ & $\begin{array}{r}5.8 \\
1.21\end{array}$ \\
\hline & Average & & 94.9 & 73.6 & 71.0 & 53.0 & 95.3 & 71.3 & & 71.9 & 74.4 & 1.33 \\
\hline
\end{tabular}

* Averages of values for five periods at the plateaus. Standing values in the numerator and recumbent values in the denominator with the decimal equivalents below.

$+S=$ Standing.

$\mathbf{L}=$ Lying. 
and the experiment terminated. Experiments were conducted with the subjects quiet, comfortable and undisturbed in a room regulated at about $27^{\circ}$ C. Smoking was not permitted. Voluntary voiding was accomplished without change of posture and without significant retention as evidenced by the creatinine excretion data. While standing the subject occasionally shifted his feet or walked a few steps so as to prevent excessive venous pooling in the lower extremities. Seven experiments in four apparently healthy male subjects were done. In the experiment on $\mathrm{MK}$ on $7 / 18$ the procedure was varied only in that between noon and 10:00 P.M. of the previous day the subject ingested $200 \mathrm{mEq}$. of sodium chloride in isotonic solution in divided doses. The measurements recorded were period length, urine volume, urine and plasma osmolarity (Fiske Osmometer), urine sodium concentration (Weichselbaum-Varney Universal Spectrophotometer) and plasma and urine creatinine concentrations (16).

\section{RESULTS}

The data used hereafter (Table I) are the averages of the values for the last five periods in each position. In all subjects the plateau of urine flow during water diuresis with a large constant positive water load was lower during standing than during recumbency. In one subject (WS) it was as high as 89 per cent and in the other 3 was from 55 to 78 per cent of that in recumbency. Endogenous creatinine clearance during standing varied from 84 to 100 per cent of the value for lying.

During standing urine sodium concentrations were 28 to 95 per cent and urine sodium excretion rate 18 to 76 per cent of the values for recumbency. Plasma creatinine and osmolar concentrations varied little during the course of individual experiments. In 6 experiments standing osmolar clearance ranged from 52 to 77 per cent of the value while lying, while in one experiment in which urine osmolarity was slightly lower during recumbency (after change from standing to lying), standing osmolar clearance was as much as 97 per cent of the value for lying.

Free water clearance in the erect position was always less than during lying since the absolute fall in urine flow was greater than the absolute fall in osmolar clearance. In all instances creatinine $U / P$ was higher during standing. In the two experiments in which the plasma protein concentration was determined (17) in the venous blood samples (HW 3/16 and WS 3/18) the values rose 4 and 6 per cent on standing.

\section{DISCUSSION}

To permit the assumption that distal water reabsorption was absent during these experiments maximal water diuresis was employed. The validity of any inferences as to proximal versus distal sites of reabsorption depends on the validity of the two assumptions stated earlier. Change in posture from lying to standing or the reverse was used to induce changes in GFR. In a previous communication (4) the literature has been summarized to indicate that a) most workers find a fall in filtration rate on changing from the horizontal to a head-up tilt or to standing, b) all workers find falls in water and sodium excretion on changing from the horizontal to a head-up tilt or to standing. Additional relevant reports have since been published $(5,18-20)$.

Under the conditions of high water loading employed with resultant maximal rates of urine flow endogenous creatinine clearance (used as an index of GFR) was not diminished as much during standing as is usually seen with lower rates of flow. While changes in the creatinine clearance in 5 of the 7 experiments were within the limits of experimental error, values during standing never exceeded those during recumbency. We believe that GFR was really lower to a small and variable extent during standing than lying. The situation is much the same as is seen with mild unilateral renal artery constriction in the dog (1). There, as in the present experiments, fall in excretion of water and sodium was clearly evident in the presence of GFR values which in any single experiment could not with certainty be called depressed, but which were uniformly slightly lower than the control.

In each of our experiments the percentage by which urine flow is lower during standing than lying exceeds that for endogenous creatinine clearance. Under our assumptions we conclude therefore that with small lowering of GFR proximal reabsorption of sodium and water becomes more nearly complete.

Our finding is that free water clearance may be somewhat different on different occasions in the same individual in maximal water diuresis. With greater rates of urine flow greater levels of free water are achieved since the absolute differences in osmolar clearance on different occasions are 
small relative to those in urine flow. The free water values of the various periods of a plateau of a given standing or lying session did not vary among themselves by more than about 20 per cent. Since we used no solute loading in the course of an experiment we have no data on whether free water clearance at flows above those obtained by maximal sustained simple water diuresis remains constant $(9,21)$ or not $(5)$. Our values were usually in the range described by Smith (21). In subject MK greater urine flow and free water clearance were obtained after light salt loading than without loading.

Since the percentage by which free water was decreased during standing was about the same as that for decrease in urine flow it follows that distal reabsorption of sodium remains about the same percentage of the distally presented load in the two positions, but the percentage of the filtered sodium reabsorbed distally falls on standing. No information is derived as to the existence of a maximal distal tubular capacity for sodium reabsorption since the sodium load presented distally on standing approached or fell below the osmolar equivalent of the free water clearance obtaining during lying in the same experiment.

We assume that in the presence of water loading pituitary antidiuretic hormone action on the kidney is absent in both the erect and recumbent positions. Although this may be open to some question, our subjects did not have the circulatory disturbances present in the subjects of Brun, Knudsen, and Raaschou $(22,23)$. In the experiments of Pearce and Newman (19) in which water diuresis was not maximal, a head-up tilt usually produced a greater percentage fall in water excretion than in electrolyte excretion with resultant increase in electrolyte concentration. In our experiments sodium concentration was always considerably lower and osmolar concentration usually slightly lower in the erect position than in the horizontal. Rise in creatinine, inulin or mannitol $\mathrm{U} / \mathrm{P}$ cannot be taken as proof of $\mathrm{ADH}$ action since it may be seen on constriction of the aorta or of a renal artery $(1,24,25)$ where there is no reason to implicate $\mathrm{ADH}$. A rise in mannitol $U / P$ also occurs in normal or uncontrolled diabetes inspidus subjects with abdominal compression (26), although here the possibility exists that the discomfort attending the procedure may have elicited $\mathrm{ADH}$ secretion even in clinical diabetes insipidus subjects.

While the possibility of a distal $\mathrm{T}^{\mathbf{c}}{ }_{\mathrm{H}_{2} \mathrm{O}}$ process (reabsorption of water without solute) operating continuously (even in maximum water diuresis) at a level of 5 to $7 \mathrm{cc}$. per minute (27) cannot be denied, its probability is low. On the basis of a constant $\mathrm{T}^{\mathrm{c}} \mathrm{H}_{2} \mathrm{O}$ of $6 \mathrm{cc}$. per minute, calculations still show that a higher percentage of the filtered water and sodium is reabsorbed proximally on standing than on lying, and that a lower percentage of the filtered sodium is reabsorbed distally on standing, although the calculated changes are less than on the basis of our first assumption.

\section{SUM MARY}

The effects of posture on urine flow, free water clearance, osmolar clearance, endogenous creatinine clearance and sodium excretion were determined in normal subjects in maximal water diuresis. It is assumed that distal water reabsorption is abolished and that proximal reabsorption is isosmotic. The findings are interpreted to mean that a higher percentage of the filtered water and sodium is reabsorbed proximally on standing than on lying and that a lower percentage of the filtered sodium (and a lower absolute amount per unit time) is reabsorbed distally on standing. The percentage reabsorbed of the distally delivered sodium load is the same for lying and standing. Slightly lower endogenous creatinine clearance values were observed on standing, although the differences between standing and lying were less than are seen at urine flows below maximum. The percentage changes in creatinine clearance were less than in excretion of water and sodium and in free water and osmolar clearances.

\section{REFERENCES}

1. Mueller, C. B., Surtshin, A., Carlin, M. R., and White, H. L., Glomerular and tubular influences on sodium and water excretion. Am. J. Physiol., 1951, 165, 411.

2. Ni, T-G., and Rehberg, P. B., On the influence of posture on kidney function. J. Physiol., 1931, 71, 331.

3. White, H. L., and Rolf, D., Effects of exercise and of some other influences on the renal circulation in man. Am. J. Physiol., 1948, 152, 505. 
4. Netravisesh, V., Effects of posture and of neck compression on outputs of water, sodium and creatinine. J. Applied Physiol., 1953, 5, 544.

5. Rosenbaum, J. D., Nelson, W. P., III, Strauss, M. B., Davis, R. K., and Rossmeisl, E. C., Variation in the diuretic response to ingested water related to the renal excretion of solutes. J. Clin. Invest., 1953, 32, 394.

6. Duggan, J. J., and Pitts, R. F., Studies on diuretics. I. The site of action of mercurial diuretics. J. Clin. Invest., 1950, 29, 365.

7. Pitts, R. F., and Duggan, J. J., Studies on diuretics. II. The relationship between glomerular filtration rate, proximal tubular absorption of sodium and diuretic efficacy of mercurials. J. Clin. Invest., 1950, 29, 372.

8. Dale, R. A., and Sanderson, P. H., The mode of action of a mercurial diuretic in man. J. Clin. Invest., 1954, 33, 1008.

9. Wesson, L. G., Jr., and Anslow, W. P., Jr., Effect of osmotic and mercurial diuresis on simultaneous water diuresis. Am. J. Physiol., 1952, 170, 255.

10. Weston, R. E., Grossman, J., and Leiter, L., The effect of mercurial diuretics on renal ammonia and titratable acidity production in acidotic human subjects with reference to site of diuretic action. J. Clin. Invest., 1951, 30, 1262.

11. Wesson, L. G., Jr., Anslow, W. P., Jr., and Smith, H. W., The excretion of strong electrolytes. Bull. New York Acad. Med., 1948, 24, 586.

12. Walker, A. M., Hudson, C. L., Findley, T., Jr., and Richards, A. N., The total molecular concentration and the chloride concentration of fluid from different segments of the renal tubule of amphibia. The site of chloride reabsorption. Am. J. Physiol., 1937, 118, 121.

13. Walker, A. M., Bott, P. A., Oliver, J., and MacDowell, M. C., The collection and analysis of fluid from single nephrons of the mammalian kidney. Am. J. Physiol., 1941, 134, 580.

14. Wesson, L. G., Jr., and Anslow, W. P., Jr., Excretion of sodium and water during osmotic diuresis in the dog. Am. J. Physiol., 1948, 153, 465.
15. Mudge, G. H., Foulks, J., and Gilman, A., Effect of urea diuresis on renal excretion of electrolytes. Am. J. Physiol., 1949, 158, 218.

16. Bonsnes, R. W., and Taussky, H. H., On the colorimetric determination of creatinine by the Jaffe reaction. J. Biol. Chem., 1945, 158, 581.

17. Lowry, O. H., and Hunter, T. H., The determination of serum protein concentration with a gradient tube. J. Biol. Chem., 1945, 159, 465.

18. Goodyer, A. V. N., and Seldin, D. W., The effects of quiet standing on solute diuresis. J. Clin. Invest., 1953, 32, 242.

19. Pearce, M. L., and Newman, E. V., Some postural adjustments of salt and water excretion. J. Clin. Invest., 1954, 33, 1089.

20. Holland, B. C., and Stead, E. A., Jr., Electrolyte excretion after single doses of ACTH, cortisone, desoxycorticosterone glucoside, and motionless standing. J. Clin. Invest., 1954, 33, 132.

21. Smith, H. W., Renal excretion of sodium and water. Federation Proc., 1952, 11, 701.

22. Brun, C., Knudsen, E. O. E., and Raaschou, F., The influence of posture on the kidney function. I. The fall of the diuresis in the erect posture. Acta med. Scandinav., 1945, 122, 315.

23. Brun, C., Knudsen, E. O. E., and Raaschou, F., Kidney function and circulatory collapse. Post-syncopal oliguria. J. Clin. Invest., 1946, 25, 568.

24. Thompson, D. D., and Pitts, R. F., Effects of alterations of renal arterial pressure on sodium and water excretion. Am. J. Physiol., 1952, 168, 490.

25. Selkurt, E. E., Physical factors in relation to electrolyte and water excretion. Conference on Renal Function. New York, Josiah Macy, Jr., Foundation, 1951, vol. 3, p. 103.

26. Bradley, S. E., Mudge, G. H., Blake, W. D., and Alphonse, $P$., The effect of increased intra-abdominal pressure on the renal excretion of water and electrolytes in normal human subjects and in patients with diabetes insipidus. Acta clin. belg., 1955, 10, 209.

27. Wesson, L. G., Jr., and Anslow, W. P., Jr., Effect of osmotic and mercurial diuresis on simultaneous water diuresis. Am. J. Physiol., 1952, 170, 255.

\section{SPECIAL NOTICE TO SUBSCRIBERS}

Post Offices will no longer forward the Journal when you move.

Please notify The Journal of Clinical Investigation, Business Office, 622 West 168th Street, New York 32, N. Y. at once when you have a change of address, and do not omit the zone number if there is one. 